\title{
Spotlight on Plasmodium falciparum evolutionary system in the southeastern Atlantic forest
}

\author{
Gabriel Zorello Laporta ${ }^{1,2 *}$ \\ ${ }^{1}$ Universidade Federal do ABC, Centro de Engenharia, Modelagem e Ciências Sociais Aplicadas, Av. dos Estados, \\ 5001, Santo André, SP, Brazil. \\ ${ }^{2}$ Faculdade de Medicina do ABC, Setor de Pós-graduação, Pesquisa e Inovação, Av. Lauro Gomes, \\ 2000, Santo André, SP, Brazil. \\ *Corresponding author: Gabriel ZorelloLaporta, e-mail: gabriel.laporta@ufabc.edu.br
}

LAPORTA, GZ. Spotlight on Plasmodium falciparum evolutionary system in the southeastern Atlantic forest. Biota Neotropica. 17(3): e20160314. http://dx.doi.org/10.1590/1676-0611-BN-2016-0314

\begin{abstract}
Malaria elimination is now set to occur in Brazil until 2030. While this achievement is feasible, as it is for other endemic regions worldwide, it is important to recognize resistance of parasites and vectors against anti-malarial interventions. Resistance against drugs and insecticides can lead to discontinuities of malaria transmission, known as residual malaria transmission. Herein, we described a novel phenomenon that is occurring in a residual malaria transmission scenario in the southeastern Atlantic forest. This novel phenomenon does not belong to what is known and therefore we decided to explain it based on an evolutionary perspective. Although it shall not be viewed as a threat to public health, the phenomenon has important aspects that should be highlighted. Specifically, it represents an adaptation of $P$. falciparum among vectors and hosts in the southeastern Atlantic forest. Knowledge about this phenomenon could be of importance, including to the on-going malaria elimination programs.
\end{abstract}

Keywords: Anopheles, Biological Evolution, Malaria, Plasmodium falciparum, Rainforest.

\section{Destaque para o sistema evolutivo de Plasmodium falciparum no sudeste da Mata Atlântica}

Resumo: A eliminação da malária pode ocorrer no Brasil antes de 2030. Embora seja viável no Brasil e em outras regiões endêmicas do mundo, reconhece-se a importância da resistência de parasitos e vetores às intervenções. A resistência contra drogas e inseticidas pode levar à malária residual. Aqui, descrevemos um novo fenômeno que está ocorrendo em um cenário residual de transmissão de malária no sudeste da Mata Atlântica. Esse fenômeno não faz parte do conhecimento atual e, portanto, propomos uma perspectiva evolutiva para explicá-lo. Não sugerimos uma nova ameaça à saúde pública; entretanto, ressaltam-se aspectos importantes sobre o fenômeno. Especificamente, o fenômeno representa uma adaptação de $P$. falciparum entre vetores e hospedeiros no sudeste da Mata Atlântica. O conhecimento sobre essa adaptação pode ser importante para os programas de eliminação da malária em andamento.

Palavras-chave: Anopheles, Evolução Biológica, Floresta Tropical, Malária, Plasmodium falciparum.

Malaria eradication is the permanent reduction to zero of the incidence of infection worldwide. In contrast, elimination is the permanent reduction to zero of the incidence of Plasmodium infection on a country or regional scale. A new perspective on, and enthusiasm for, malaria elimination in this century have together overcome the failure of the first malaria eradication program (1950 - 1969) (Cotter et al. 2013). The current support appears to be justified, because the malaria burden is declining in endemic countries, 18 of which have reached the goal of elimination between 2007-2015 (WHO 2016). The on-going malaria elimination programs adopted by many endemic countries are making headway, with a general understanding that elimination is possible in Brazil until 2030 (Ferreira \& Castro 2016).

Interventions (e.g., drug administration on infected individuals, vector control management) can control malaria transmission and thus have strong impact on these malaria elimination programs (Cotter et al. 2013). Resistant fraction of parasite and vector populations, however, can persist in the environment of transmission even after intensive malaria control programs (Haji et al. 2013, Barbosa et al. 2014, Guyant et al. 2015, Waltmann et al. 2015). This strong selective pressure on Plasmodium parasite and Anopheles mosquito populations had been documented in many situations in the past and have been still occurring nowadays (Najera et al. 2011, Haji et al. 2013, Waltmann et al. 2015). The mechanism of resistance is evolutionary-based, because it favors adaptation of Plasmodium transmission among vectors and hosts, leading to rare and discontinuous cycles (Corey et al. 2016, Chang et al. 2016). Such discontinuity in transmission dynamics is represented by persistent transmission post-intervention and occurs when frequent malaria outbreaks are replaced by rare randomly-distributed malaria clusters in an endemic region, i.e., residual malaria transmission (Killeen 2014). Residual malaria transmission is often overlooked because there is neither a strong nor an obvious impact on public health. 
The southeastern Atlantic forest is historically known to hold a residual malaria transmission recognized as 'bromeliad-malaria'. The main characteristics are: very few annually reported Plasmodium vivax cases among residents and high abundance of the primary vector Anopheles cruzii, a forest-loving bromeliad-mosquito species (Gadelha 1994). This paradigmatic scenario has been challenged recently, resulting in a new puzzle to be solved (Maselli et al. 2014, Sallum et al. 2014, Laporta et al. 2015). While these authors recognize that systematic studies and specific funding are needed, an effort towards solving that puzzle is made and thus a novel theoretical view is hypothesized in the present work.

\section{Setting the Scene: a New Puzzle}

Plasmodium falciparum is the most threatening malaria-parasite because of the magnitude of deaths attributable to this species. In many parts of the world, however, scientists are observing high prevalence of sub-microscopic $P$. falciparum infections among asymptomatic residents (Elbadry et al. 2015, Tiedje et al. 2017). For instance, we investigated blood samples for Plasmodium falciparum contamination in a center of blood donation in hospital of the University of São Paulo. As a result, we found $10.6 \%$ prevalence of $P$. falciparum subclinical infections among residents living in the southeastern Atlantic forest (Maselli et al. 2014). On the one hand, this evidence represented an institutional incident among scientists and directorial board of blood donation center (Mendrone et al. 2014). On the other hand, it allowed thinking more theoretically and concluding that an interesting phenomenon related to evolution of malaria transmission system was taking place (Sallum et al. 2014).

Given the hypothesis of locally $P$. falciparum transmission in the southeastern Atlantic forest, we tested field collected anophelines throughout that region for malaria parasites. We found $4.4 \%(21 / 480)$ of $P$. falciparum-infected anophelines and $99 \%$ similarity of the $P$. falciparum $18 \mathrm{~S}$ rDNA fragments shared with $P$. falciparum sequences previously isolated from wild monkeys in Amazonia (Laporta et al. 2015). With the real-time quantitative curves from Laporta et al. 2015, we estimated the average number of $P$. falciparum sporozoites per anopheline (Figure 1).

The scientific puzzle-solving game is now setup. It has the following pieces of evidence: 1) high prevalence of $P$. falciparum subclinical infections among residents of the southeastern Atlantic forest, 2) widespread

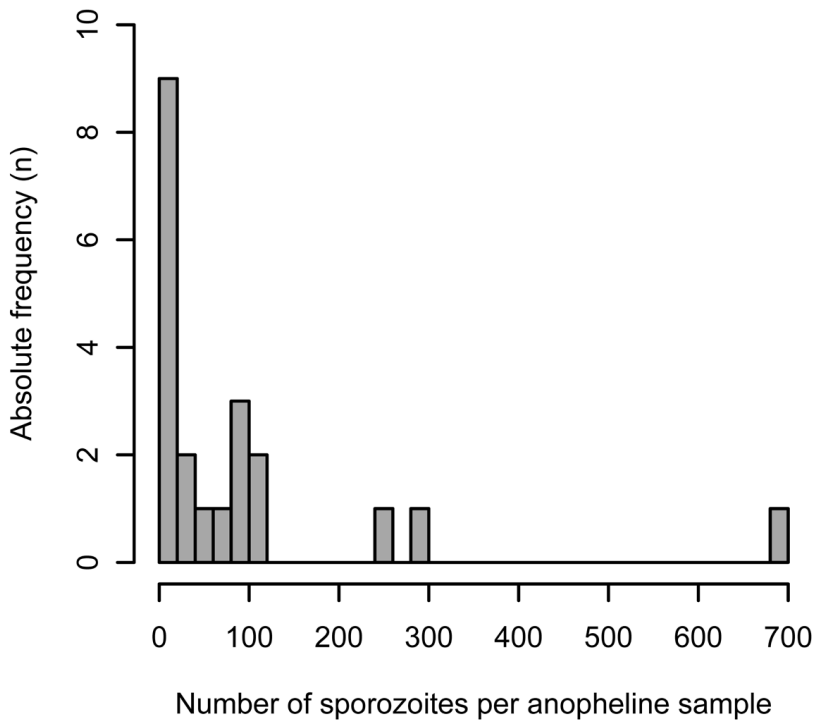

Figure 1. Number of $P$. falciparum sporozoites per anopheline according to the real-time quantitative curves from Laporta et al. 2015. distribution of $P$. falciparum-infected anophelines in the same region, 3 ) close relationship between $P$. falciparum found in anophelines with non-human primates, and 4) low number of $P$. falciparum sporozoites in anophelines. One could see all these pieces of information as totally independent from each other. On the contrary, other would view all of them connected on a web of causal mechanisms.

Considering the assumption that these evidences are interconnected, the next step is very straightforward: to propose an explanation that combines it all in a single theoretical hub. Acknowledging that a malaria transmission system is flexible and persistent, the working hypothesis herein is the evolution pathways of such a system under anti-malarial intervention.

\section{Working Hypothesis: Malaria Transmission System Under Anti-malarial Intervention}

Mechanisms of resistance to anti-malarial interventions are still a threat to the programs of malaria elimination today. For instance, the spread of artemisinin-resistant P. falciparum in the Greater Mekong subregion, Asia is challenging the current triumph, i.e., artemisinin combination therapy, in the so-called malaria elimination era (Imwong et al. 2017). The Lancet Infectious Diseases' editorial ("Is malaria elimination within reach?"; 2017) is not more optimistic than results by Imwong et al. (2017).

When a malaria transmission system is resistant to anti-malaria interventions, it means that clinical cases of malaria will keep continuing. Other possibilities are that anti-malarial interventions can kill the most pathogenic and virulent fractions of the malaria parasites involved, resulting in sub-microscopic (Elbadry et al. 2015, Tiedje et al. 2017) and/or sub-clinical infections (Maselli et al. 2014). Individuals had few clinical symptoms and sub-microscopic $P$. falciparum infections in Central America (Elbadry et al. 2015) and Africa (Tiedje et al. 2017), meaning that transmission is still occurring despite anti-malarial interventions. Sub-clinical P. falciparum infections in Maselli et al. (2014) are yet more complex, because $100 \%$ of tested individuals had no symptoms. The pathways that malaria transmission systems create to resist against anti-malaria interventions should be less looked from a medical view and more studied from an evolutionary perspective.

In ecological systems, one important property is resilience of fundamental processes for a system under disturbance (Holling 1973). Resilience has two dimensions: 1) stochastic, variations on the behavior of a system under disturbance without losing the deterministic dimension, 2) deterministic, achievement of the goals of such a system (Holling 1973). Deterministic dimension of a malaria transmission system is to persist on parasite transmission among vectors and hosts. When an anti-malaria intervention collides with such a deterministic dimension, malaria transmission system's stochastic dimension finds new pathways for keeping up the transmission goal. The compounds of a malaria transmission system are the key to understand its resilience. For instance, while parasite's asexual reproduction is made within host, parasite's sexual reproduction inside mosquito produces important genetic variability for malaria transmission (Talman et al. 2004). It seems therefore that biology of mosquito vectors should contribute decisively to the behavior of stochastic dimension of malaria transmission system.

\section{Biology of Malaria Vectors and the Transmission of Parasites among Hosts}

Several Anopheles species in many parts of the African continent, Western Pacific, and throughout the Amazon, can transmit malaria parasites to humans (Massey et al. 2016). Biology of each of these anopheline species defines important features of malaria epidemiology. For instance, forested anopheline species are highly associated with transmission of 
Plasmodium in forested landscapes in the Western Pacific. Anopheline species associated with open and deforested areas are abundant and make thousands of people sick annually in urbanized zones in Sub-Saharan Africa (Guerra et al. 2006). Anopheles darlingi is associated with forest fringe, resulting in the current paradigm of malaria transmission called 'the frontier malaria' in Amazon (Barros \& Honório 2015). Plasmodium falciparum transmission in the southeastern Atlantic forest (Maselli et al. 2014, Laporta et al. 2015) could also be explained by means of biology of the main malarial vector in this system, An. cruzii.

Anopheles cruzii is a forest-loving species that inhabits the southeastern Atlantic forest. Beyond its importance as a vector of $P$. vivax to humans, it is related to transmission of Plasmodium simium among monkeys and/or humans (Pina-Costa et al. 2014). Recently, Brasil et al. (2017) suggested that transmission of $P$. simium to humans may have been neglected because it seems more important than previously thought. Additionally, out of twenty-one (4.4\%) P. falciparum-infected anophelines found in the southeastern Atlantic forest, eighteen (3.75\%) were An. cruzii (Laporta et al. 2015). Considering that An. cruzii can interchangeably transmit $P$. vivax to humans and $P$. simium to monkeys and/or humans, it is possible that $P$. falciparum circulation in the southeastern Atlantic forest is helped by vector contact with both humans and monkeys.

Beyond the vector ability of An. cruzii, this species seems to live longer than other anophelines. Anopheles cruzii females had been recaptured up to two months after the release date (Santos 2001). This means that a malaria parasite can have a long period for completing its development inside this mosquito (Poulin 2011). Availability of such a long period means that transmission will be exponentiated. But, what would happen if a long period for parasite development is combined with efficient anti-malarial interventions? Considering the efficient anti-malarial interventions in the southeastern Atlantic forest (Smith 1952) and the current low number of sporozoites found in this mosquito species (Figure 1), it is possible that a selection of a less efficient parasite occurred.

\section{Plasmodium falciparum Evolutionary System in the Southeastern Atlantic Forest}

Oocytes of $P$. falciparum were commonly found in An. cruzii females and other anophelines during malaria epidemics period that reached the cities of Blumenau, Joinville, and Florianopolis in the 1940s (Smith 1952). Plasmodium falciparum was considered eliminated in the southeastern Atlantic forest after the malaria eradication programme in the 1950-60s (Gadelha 1994, Griffing et al. 2015). A long gap lasted for approximately 40 years $(1970-2010)$ in when $P$. falciparum circulation had not been documented in this region. It is either possible that this parasite remained in silent cycles inside the forest with monkeys as a reservoir or that it was re-introduced by migration of infected humans from endemic counties of Amazon without being noticed. Anyway, a cornerstone publication was made in 2008 suggesting that Alouatta monkeys could be reservoirs of $P$. falciparum in the southeastern Atlantic forest (Duarte et al. 2008). Following, a high proportion of $P$. falciparum was found throughout the southeastern Atlantic forest, mainly in An. cruzii mosquitoes, and infecting high fractions of asymptomatic human hosts and potentially circulating among reservoir monkeys (Maselli et al. 2014, Laporta et al. 2015).

Notwithstanding the above, having a P. falciparum adapted to monkeys would be an idiosyncrasy. Not only an idiosyncrasy, but this adaptation has not yet been proved or published. The most comprehensive study on interactions among human malaria parasites on non-human primates by Liu et al. (2010) showed that P. falciparum is not infecting great apes in Africa nowadays. Great apes have infections with species closely related to P. falciparum; for instance, gorillas can be infected by P. praefalciparum (Liu et al. 2010). Then, there is not a scientific consensus that it can occur species permeability (Molina-Cruz et al. 2016). In other words, there is not a strong support for the parasite being transmitted in both directions: 1) from humans to apes, and 2) from apes to humans. This is because infections found in nature so far, apes with $P$. falciparum, were not effective (Loy et al. 2016).

Now we are set into the most important step of this puzzle solving game. While $P$. falciparum should not circulate among monkeys and humans, a novel system of $P$. falciparum transmission is taking place in the southeastern Atlantic forest. In such malaria transmission system, two mechanisms may be contributing to the P. falciparum circulation: 1) Elevated host tolerance (asymptomatic infected humans; Maselli et al. 2014), 2) Inefficient vector adaptation (low number of $P$. falciparum sporozoites in An. cruzii; Laporta et al. 2015, Figure 1). These mechanisms could be further related to the evolution of $P$. falciparum resilience.

\section{Open Remarks for New Opportunities}

A close adaptation of $P$. falciparum to its vector could occur. This adaptation was discussed by Sallum et al. (2014) and exemplified by Molina-Cruz et al. (2016). An adaptation would be selected in the environment if $P$. falciparum could not cause symptoms in human hosts (as evidentiated in Maselli et al. 2014); because then it would be invisible to the surveillance system, which is based mainly on symptomatic malaria individuals. For instance, São Paulo State has not reported any autochthonous case of $P$. falciparum in the southeastern Atlantic forest since 1980 (Couto et al. 2010, São Paulo 2017).

The average number of sporozoites in the glands of an infective anopheline is expected to be 1,000 (Ross 1910). We estimated a low mean number (95) of $P$. falciparum sporozoites in 18 An. cruzii and 3 other anophelines in the southeastern Atlantic forest (Figure 1). This low number in the mosquito's glands would lead to an absence of viable sporozoites to be inoculated into humans and thus no transmission should occur. However, we also observed a high prevalence of $P$. falciparum subclinical infections in humans (Maselli et al. 2014). What is the underlying mechanism behind these evidences?

The high prevalence of $P$. falciparum subclinical infections in humans could be triggered by the low number of sporozoites in An. cruzii in the southeastern Atlantic forest, evidentiated in Laporta et al. 2015 (Figure 1). Exposure to an irrelevant load of inoculum of $P$. falciparum could help in decreasing the recovery time among susceptible hosts. These exposures with a very low load of $P$. falciparum along time could serve as a natural immunization for residents in the southeastern Atlantic forest.

Adaptation of $P$. falciparum to sylvatic transmission among exclusively asymptomatic humans is hypothetically suggested as belonging to evolution of $P$. falciparum resilience. Resilience in such case is defined as the capacity of an infectious disease to adapt to an environment under a disturbance regime represented by an eradication programme.

To prove evolution of resilience is not trivial. It needs data and evidences within a profound temporal framework, such as shown in Figure 2, which is not always available, particularly in the southeastern Atlantic forest, a neglected malaria region.

Figure 2 is a hypothetical temporal framework that represents steps of malaria transmission system. Prior to the 1870 s, during the pre-biological invasion phase, the only known malaria-parasite was $P$. simium in non-human primates, and the prevalent mosquitoes were identified as Kerteszia species. From approximately 1890-1910, massive European immigration to southern Brazil occurred (Carvalho Filho \& Monasterio 2012), a biological invasion that resulted in forest clearing, the emergence of Nyssorhynchus species and a notable increase in P. falciparum and $P$. vivax. This invasion resulted in a subsequent acute malaria epidemic that lasted for approximately 20 years (1930-1950). During this time, both Kerteszia and Nyssorhynchus species transmitted both human parasites at an unprecedented scale (Smith 1950). By the 1950s the worldwide malaria 

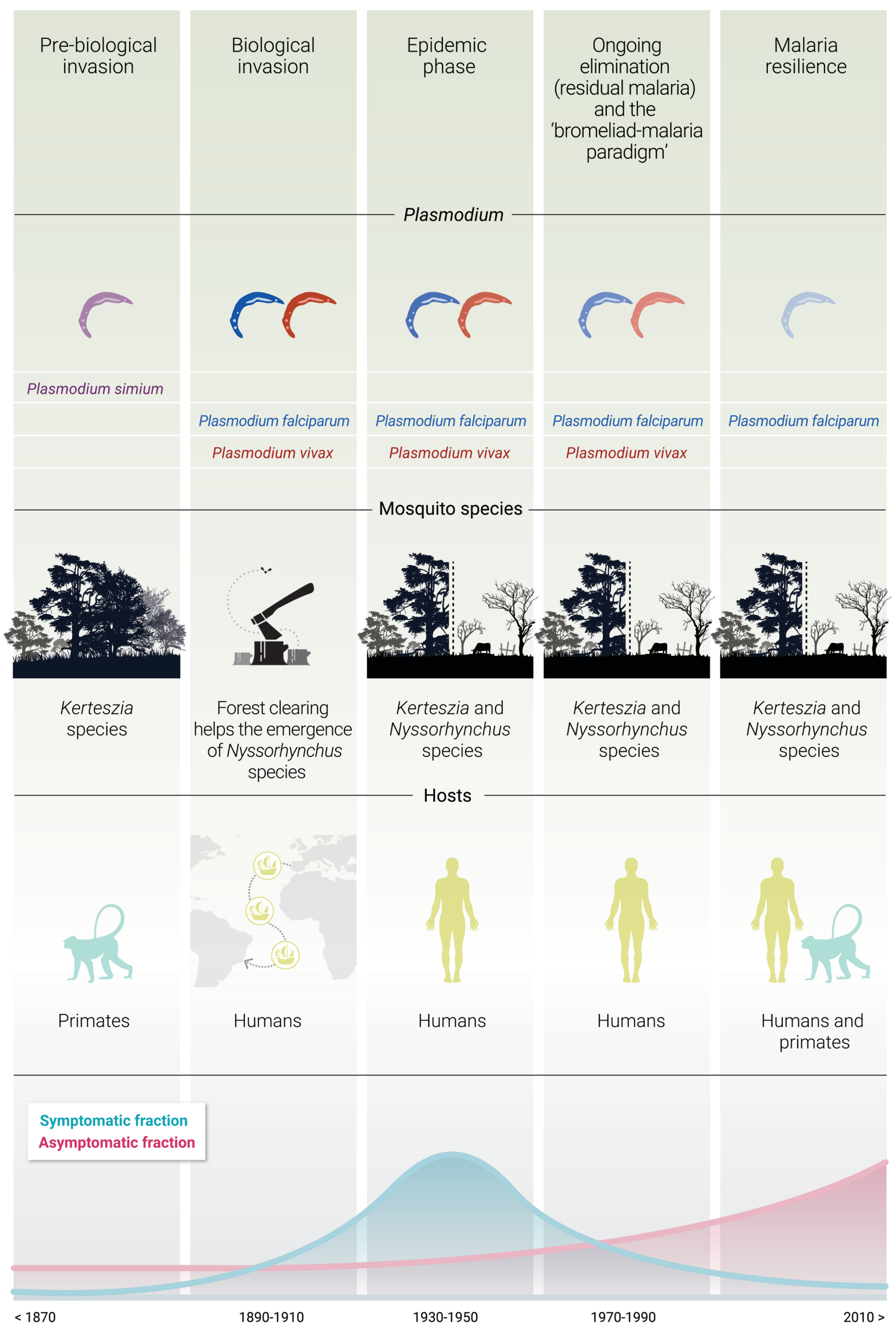

Figure 2. Hypothetical temporal framework that represents steps of malaria transmission system. 
burden was so high that governments of endemic countries began to take serious control measures instigated by the Global Malaria Eradication Program (GMEP). In Brazil, transmission decreased after an intense eradication campaign that included chloroquine treatment of infected humans and control of Kerteszia mosquitoes by rapid bromeliad destruction (Griffing et al. 2015). During this elimination phase (1970-1990) in the Atlantic forest, chloroquine resistance plus vector persistence in forest fragments resulted in residual malaria, known as the bromeliad-malaria paradigm (Gadelha 1994). This paradigm is essentially the dynamics of vivax-malaria transmitted by local Kerteszia and Nyssorhynchus vectors. Finally, the finding of P. falciparum in humans who have never travelled to the Amazon or any other malaria endemic region, suggests an alternative cycle of transmission dynamics may have evolved, which is recognized herein as evolution of $P$. falciparum resilience (Figure 2).

It should be further suggested studies in such an intriguing scenario of $P$. falciparum resilience. This may be relevant because it may reveal important aspects of evolution of malaria transmission under environment disturbances (i.e., anti-malarial interventions). This should be therefore important to the implementation of malaria elimination programs in endemic countries.

\section{Funding}

São Paulo Research Foundation (FAPESP) and BIOTA-FAPESP Program (n. 2014/09774-1, 2015/09669-6).

\section{Acknowledgements}

Jan E. Conn and Maria A. M. Sallum for helping improvement of earlier versions. Anonymous reviewer for making insightful considerations.

\section{Author Contributions}

Gabriel Zorello Laporta: contribution in the concept and design of the study; contribution to manuscript preparation and critical revision.

\section{Conflicts of interest}

The author declares there are not conflicts of interest related to the publication of this manuscript.

\section{References}

BARBOSA, S., GOZZE, A. B., LIMA, N. F., BATISTA, C. L., BASTOS, M. S., NICOLETE, V. C., FONTOURA, P. S., GONÇALVES, R. M., VIANA, S. A. S., MENEZES, M. J., SCOPEL, K. K. G., CAVASINI, C. E., MALAFRONTE, R. S., SILVA-NUNES, M., VINETZ, J. M., CASTRO, M. C. \& FERREIRA, M. U. 2014. Epidemiology of disappearing Plasmodium vivax malaria: a case study in rural Amazonia. PLoS Negl. Trop. Dis. 8(8):e3109.

BARROS, F.S.M \& HONÓRIO, N.A. 2015. Deforestation and malaria on the Amazon Frontier: larval clustering of Anopheles darlingi (Diptera: Culicidae) determines focal distribution of malaria. Am. J. Trop. Med. Hyg. 93:939-953.

BRASIL, P., ZALIS, M.G., PINA-COSTA, A., SIQUEIRA, A.M., JUNIOR, C.B., SILVA, S., AREAS, A.L.L., PELAJO-MACHADO, M., ALVARENGA, D.A.M., SANTELLI, A.C.F.S., ALBUQUERQUE, H.G., CRAVO, P., ABREU, F.V.S., PETERKA, C.L., ZANINI, G.M. SUAREZ-MUTIS, M.C., PISSINATTI, A., LOURENCO-DE-OLIVEIRA, R., BRITO, C.F.A., FERREIRA-DA-CRUZ, M.F., CULLETON, R. \& DANIEL-RIBEIRO, C.T. 2017. Plasmodium simium causing human malaria: a zoonosis with outbreak potential in the Rio de Janeiro Brazilian Atlantic forest. bioRxiv. doi: https://oi.org/10.1101/122127.

CARVALHO FILHO, I. \& MONASTERIO, L. 2012. Immigration and the origins of regional inequality: Government-sponsored European migration to southern Brazil before World War I. Reg. Sci. Urban. Econ. 42:794-807.
CHANG, X., ZHONG, D., LO, E., FANG, Q., BONIZZONI, M., WANG, X., LEE, M.C., ZHOU, G., ZHU, G., QIN, Q., CHEN, X., CUI, L. \& CHEN, X. 2016. Landscape genetic structure and evolutionary genetics of insecticide resistance gene mutations in Anopheles sinensis. Parasit.Vectors. 9:228.

COREY, V. C., LUKENS, A. K., ISTVAN, E. S., LEE, M. C., FRANCO, V., MAGISTRADO, P., COBURN-FLYNN, O., SAKATA-KATO, T., FUCHS, O., GNÄDIG, N.F., GOLDGOF, G., LINARES, M., GOMEZ-LORENZO, M.G., CÓZAR, C., LAFUENTE-MONASTERIO, M.J., PRATS, S., MEISTER, S., TANASEICHUK, O., WREE, M., ZHOU, Y., WILLIS, P.A., GAMO, F.J., GOLDBERG, D.E., FIDOCK, D.A., WIRTH, D.F. \& WINZELER, E.A. 2016. A broad analysis of resistance development in the malaria parasite. Nature. Comm. 7:11901.

COTTER, C., STURROCK, H. J., HSIANG, M. S., LIU, J., PHILliPS, A. A., HWANG, J., GUEYE, C. S., FULLMAN, N., GOSLING, R. D. \& FEACHEM, R. G. 2013. The changing epidemiology of malaria elimination: new strategies for new challenges. Lancet. 382(9895): 900-911.

COUTO, R.D'A., LATORRE, M.R.D.O., DI SANTI, S.M. \& NATAL, D. 2010. Autochthonous malaria notified in the State of São Paulo: clinical and epidemiological characteristics from 1980 to 2007. Rev. Soc. Bras. Med. Trop. 43:52-8.

DUARTE, A.M.R.C., MALAFRONTE, R.S., CERUTTI JR, C., CURADO, I., PAIVA, B.R., MAEDA, A.Y., YAMASAKI, T., SUMMA, M.E., NEVES, D.V.D.A., DE OLIVEIRA, S.G. \& GOMES, A.C. 2008. Natural Plasmodium infections in Brazilian wild monkeys: Reservoirs for human infections? Acta Trop. 107:179-85.

ELBADRY, M.A., AL-KHEDERY, B., TAGLIAMONTE, M.S., YOWELL, C.A., RACCURT, C.P., EXISTE, A., BONCY, J., WEPPELMANN, T.A., BEAU DE ROCHARS, V.E.M., LEMOINE, J.F., OKECH, B. A. \& DAME, J.B. 2015. High prevalence of asymptomatic malaria infections: a cross-sectional study in rural areas in six departments in Haiti. Malaria J. 14:510.

FERREIRA, M.U. \& CASTRO, M.C. 2016. Challenges for malaria elimination in Brazil. Malaria J. 15: 284.

GADELHA, P. 1994. From "forest malaria" to "bromeliad malaria": a case-study of scientific controversy and malaria control. Parassitologia. 36(1-2):175-95.

GRIFFING, S.M., TAUIL, P.L., UDHAYAKUMAR, V. \& SILVA-FLANNERY, L. 2015. A historical perspective on malaria control in Brazil. Mem. Inst. Oswaldo Cruz. 110(6):701-718.

GUERRA, C.A., SNOW, R.W. \& HAY, S.I. 2006. A global assessment of closed forests, deforestation and malaria risk. Ann. Trop. Med. Parasitol. 100:189-204.

GUYANT, P, CORBEL, V., GUÉRIN, P. J., LAUTISSIER, A., NOSTEN, F., BOYER, S., COOSEMANS, M., DONDORP, A. M., SINOU, V., YEUNG, S. \& WHITE, N. 2015. Past and new challenges for malaria control and elimination: the role of operational research for innovation in designing interventions. Malaria J. 14:279.

HAJI, K. A., KHATIB, B. O., SMITH, S., ALI, A. S., DEVINE, G. J., COETZEE, M. \& MAJAMBERE, S. 2013. Challenges for malaria elimination in Zanzibar: pyrethroid resistance in malaria vectors and poor performance of long-lasting insecticide nets. Parasit. Vectors. 6:82.

HOLLING, C.S. 1973. Resilience and stability of ecological systems. Annu. Rev. Ecol. Syst. 4:1-23.

IMWONG, M., SUWANNASIN, K., KUNASOL, C., SUTAWONG, K., MAYXAY, M., REKOL, H., SMITHUIS, F.M., HLAING, T.M., TUN, K.M., VAN DER PLUIJM, R.W., TRIPURA, R., MIOTTO, O., MENARD, D., DHORDA, M., DAY, N.P.J., WHITE, N.J. \& DONDORP, A.M. 2017. The spread of artemisininresistant Plasmodium falciparum in the Greater Mekong subregion: a molecular epidemiology observational study. Lancet Infect. Dis. 17:491-497.

KILLEEN, G.F. 2014. Characterizing, controlling and eliminating residual malaria transmission. Malaria J. 13:330.

LAPORTA, G.Z., BURATTINI, M.N., LEVY, D., FUKUYA, L.A., OLIVEIRA, T.M.P., MASELLI, L.M.F., CONN, J.E., MASSAD, E., BYDLOWSKI, S.P. \& SALLUM, M.A.M. 2015. Plasmodium falciparum in the southeastern Atlantic forest: a challenge to the bromeliad-malaria paradigm? Malaria J. 14:181.

LIU, W., LI, Y., LEARN, G.H., RUDICELL, R.S., ROBERTSON, J.D., KEELE, B.F., NDJANGO, J.B., SANZ, C.M., MORGAN, D.B., LOCATELLI, S., GONDER, M.K., KRANZUSCH, P.J., WALSH, P.D., DELAPORTE, E., 
Laporta, G.Z.

MPOUDI-NGOLE, E., GEORGIEV, A.V., MULLER, M.N., SHAW, G.M., PEETERS, M., SHARP, P.M., RAYNER, J.C. \& HAHN, B.H. 2010. Origin of the human malaria parasite Plasmodium falciparum in gorillas. Nature. 467:420-5.

LOY, D.E., LIU, W., LI, Y., LEARN, G.H., PLENDERLEITH, L.J., SUNDARARAMAN, S.A., SHARP, P.M. \& HAHN, B.H. 2016. Out of Africa: origins and evolution of the human malaria parasites Plasmodium falciparum and Plasmodium vivax. Int. J. Parasitol. 47:87-97.

MASELLI, L.M.F., LEVY, D., LAPORTA, G.Z., MONTEIRO, A.M., FUKUYA, L.A., FERREIRA-DA-CRUZ, M.F., DANIEL-RIBEIRO, C.T., DORLHIACLLACER, P.E., SALLUM, M.A.M. \& BYDLOWSKI, S.P. 2014. Detection of Plasmodium falciparum and Plasmodium vivax subclinical infection in nonendemic region: implications for blood transfusion and malaria epidemiology. Malaria J. 13:224.

MASSEY, N.C., GARROD, G., WIEBE, A., HENRY, A.J., HUANG, Z., MOYES, C.L. \& SINKA, M.E. 2016. A global bionomic database for the dominant vectors of human malaria. Sci. Data. 3:160014.

MENDRONE JR, A., CERUTTI, C., LEVI, J.E., BOUlOS, M., ARROYO SANCHEZ, M.C., MALAFRONTE, R.S., DI SANTI, S.M. \& ODONE, V. 2014. Unexpected detection of Plasmodium vivax and Plasmodium falciparum in asymptomatic blood donors: fact or artifact? Malaria J. 13:336.

MOLINA-CRUZ, A., ZILVERSMIT, M.M., NEAFSEY, D.E., HARTL, D.L. \& BARILLAS-MURY, C. 2016. Mosquito vectors and the globalization of Plasmodium falciparum malaria. Annu. Rev. Genet. 50:447-465.

NAJERA, J.A., GONZÁLEZ-SILVA, M. \& ALONSO, P.L. 2011. Some lessons for the future from the Global Malaria Eradication Programme (1955-1969). PLoS Med. 8: e1000412.

PINA-COSTA, A., BRASIL, P., DI SANTI, S.M., DE ARAUJO, M.P., SUÁREZMUTIS, M.C., SANTELLI, A.C.F.S., OLIVEIRA-FERREIRA, J., LOURENÇODE-OLIVEIRA, R. \& DANIEL-RIBEIRO, C.T. 2014. Malaria in Brazil: what happens outside the Amazonian endemic region. Mem. Inst. Oswaldo Cruz 109:618-633.

POULIN, R. 2011. Evolutionary Ecology of Parasites, 2nd. Princeton University Press, New Jersey.

ROSS, R. 1910. The prevention of malaria. John Murray, London.
SALLUM, M.A.M., DANIEL-RIBEIRO, C.T., LAPORTA, G.Z., FERREIRADA-CRUZ, M.F., MASELLI, L.M.F., LEVY, D. \& BYDLOWSKI, S.P. 2014. Finding connections in the unexpected detection of Plasmodium vivax and Plasmodium falciparum DNA in asymptomatic blood donors: a fact in the Atlantic forest. Malaria J. 13:337.

SANTOS, R.L.C. 2001. Medida da capacidade vetorial de Anopheles albitarsis e de Anopheles (Kerteszia) no Vale do Ribeira, São Paulo. Tese de doutorado, Universidade de São Paulo, São Paulo.

SÃO PAULO. http://www.saude.sp.gov.br/cve-centro-de-vigilancia-epidemiologicaprof.-alexandre-vranjac/areas-de-vigilancia/doencas-de-transmissao-por-vetorese-zoonoses/agravos/malaria/dados-estatisticos (last access 17/May/2017).

SMITH, L.B. 1952. Bromeliad Malaria. Rep. Smithsonian Inst. 385-98.

TALMAN, A. M., DOMARLE, O., MCKENZIE, F. E., ARIEY, F. \& ROBERT, V. 2004. Gametocytogenesis: the puberty of Plasmodium falciparum. Malaria J. 3(1):1.

THE LANCET INFECTIOUS DISEASES. 2017. Is malaria elimination within reach? Lancet Infect. Dis. 17:461.

TIEDJE, K.E., ODURO, A., AGONGO, G., ANYORIGIYA, T., AZONGO, D., AWINE, T., GHANSAH, A., PASCUAL, M., KORAM, K. \& DAY, K. P. 2017. Seasonal variation in the epidemiology of asymptomatic Plasmodium falciparum infections across two catchment areas in Bongo District, Ghana. Ahead of print, doi: https://doi.org/10.4269/ajtmh.16-0959

WALTMANN, A., DARCY, A. W., HARRIS, I., KOEPFLI, C., LODO, J., VAHI, V., PIZIKI, D., SHANKS, G. D., BARRY, A. E., WHITTAKER, M., KAZURA JW \& MUELLER I. 2015. High rates of asymptomatic, sub-microscopic Plasmodium vivax infection and disappearing Plasmodium falciparum malaria in an area of low transmission in Solomon Islands. PLoS Negl. Trop. Dis. 9(5): e0003758.

WHO. http://apps.who.int/iris/bitstream/10665/205565/1/WHO_HTM_GMP_2016.3_ eng.pdf?ua=1 (last access 13/Dec/2016).

Received: 21/12/2016

Revised: 27/07/2017

Accepted: 28/07/2017

Published online: 28/08/2017 